\title{
Rapid Plant Regeneration And Molecular Assessment Of Genetic Stability Using ISSR And RAPD Markers In Commercial Banana Cv. Grand Naine (G-9)
}

\author{
S. KAJLA ${ }^{1}$, D. CHOUDHARY ${ }^{1,2}$, A. K. POONIA ${ }^{1}$., J. S. DUHAN ${ }^{2}$ \\ 1. Centre for Plant Biotechnology, CCS HAU Campus, Hisar -125 004 (India) \\ 2. Department of Biotechnology, CDLU, Sirsa-125 055 (India) \\ *Corresponding author: J. S. DUHAN
}

(Fax: +91 1666 248123; e-mail: duhanjs68@gmail.com; duhanjs@rediffmail.com )

\begin{abstract}
The investigation was carried out to assess the genetic stability in tissue culture raised plants of banana cv. G-9 using random amplified polymorphic DNA (RAPD) and inter simple sequence repeats (ISSR) markers.
\end{abstract}

Aims: Molecular assessment of genetic stability of tissue culture raised plants of banana cv. G-9 using molecular markers.

\section{Material and Results:}

Apical shoots were established on medium $\mathrm{EM}_{4}\left(\mathrm{MS}+\mathrm{BAP} 4.0 \mathrm{mg} \mathrm{L}^{-1}\right)$ with maximum of 3.8 buds/explants in 2.6 days. The maximum bud multiplication with $16.5 \pm 0.06$ shoots was observed on medium $\mathrm{Ma}_{3}\left(\mathrm{MS}\right.$ medium $+5.0 \mathrm{mg} \mathrm{L}^{-1} \mathrm{BAP}+$ $0.25 \mathrm{mg} \mathrm{L}^{-1} \mathrm{NAA}$ of $+30 \mathrm{mg} \mathrm{L}^{-1} \mathrm{AdSO}_{4}$ ). The maximum rooting response (100\%) was observed on $1 / 2 \mathrm{MS}$ medium supplemented with $2.0 \mathrm{mg} \mathrm{L}^{-1} \mathrm{NAA}$ in 12.2 days. After acclimatization the hardened plants were examined for genetic stability using RAPD and ISSR primers. Total forty six (twenty six RAPD and twenty ISSR) markers were used. RAPD primers produced 87 distinct and scorable bands, with an average of 3.34 bands per primer and the amplification products range was from 100-1200 bps. The number of scorable bands for RAPD primer varied from 2 to 5 with an average of 3.34 bands per primer. ISSR primers produced 71 distinct and scorable bands in the range of 100-1000 bps and the number of scorable bands for each primer varied from 2 to 6 with an average of 3.55 bands per primer.

\section{Conclusion:}

Similar profile with monomorphic bands was observed for all the tissue culture raised plants when compared to mother plant in both types of markers used. These results corroborate the fact that plant tissue culture technology has immense importance for production of true to type of planting material.

\section{Indexing terms/Keywords}

Banana cv Grand naine (G-9); genetic stability; RAPD and ISSR Markers

\section{Academic Discipline and Sub-Disciplines}

Plant Biotechnology

\section{Subject Classification}

Biotechnology

\section{Type (Method/Approach)}

\section{Council for Innovative Research}

Peer Review Research Publishing System

Journal: JOURNAL OF ADVANCES IN BIOTECHNOLOGY

Vol. 4, No. 3.

www.cirjbt.org , jbteditor@gmail.com 


\section{INTRODUCTION}

Banana is a basic food source for millions of people in developing countries in the tropics and subtropics [1]. The plant belongs to family Musaceae and is one of the oldest fruits of the world [2] .The crop ranks fourth in terms of production in the world and is second most significant fruit crop in India next to mango [3]. Fruits of the plant are good source of proteins, carbohydrates, vitamins, minerals such as potassium, sodium, calcium and magnesium along with trace amounts of iron, zinc and carotenoids [4].

Conventional propagation generally leads to production of 4-5 suckers from single plant but through in vitro propagation, a large amount of true to type and disease free planting material can be obtained $[5,6,7,8,9,10]$. The tissue culture technique was successfully used for in vitro multiplication of a particular genotype $[11,12,13,14,15]$. The application of plant growth regulators during in vitro multiplication of plants may lead to genetic instability in plants. Hence it is mandatory to check for genetic stability of in vitro raised plants. The precise monitoring of quality control during in vitro multiplication and analysis of tissue culture raised plants by using simple and routine method is prerequisite step in micropropagation [16].

During large scale in vitro production, the plants may lead to genetic changes and the product may not be identical to the mother plant $[17,18]$. The failure to assess the morphological polymorphism in plants does not negate the possibility of genetic variations and it requires critical analysis. In order to assess genetic variability, reliable methods of identification are also required for the establishment of plant variety rights [19]. Unambiguous identification is especially important in a clonally-propagated crop such as banana [20]. Commercial cultivators need to be sure that they are investing their time and money in propagating the specific cultivar which are true to type in nature. Various methods can be used to detect and monitor in vitro raised plants. The most reliable method is the use of molecular marker techniques [18]. The molecular marker technologies have become a powerful tool in crop improvement through their use in germplasm characterization and fingerprinting, genetic analysis, linkage mapping, and molecular breeding. Identification of possible somaclonal variants at an early stage of development is considered to be very useful for quality control in plant tissue culture, transgenic plant production and in the introduction of variants [21]. Genetic stability of micropropagated plants and morphologically similar genotypes using molecular markers have been reported in many plants like Chlorophytum borivilianum [22] Curcuma sp. [23], Zingiber rubens [24] , strawberry [25], wheat [26], rice [27], eastern cottonwood [28] and date palm [29, 30] including banana [31]. RAPD and ISSR markers being simple and less laborious can be used for genetic stability testing of micropropagated plants. Sheidai et al. [32] used RAPD markers to detect the somaclonal variations in the tissue culture raised plants of banana cultivar Cavendish Dwarf. In the present study, the genetic stability and uniformity of the important banana cultivar Grand naine (G-9) produced through tissue culture technique was examined by using RAPD and ISSR markers.

\section{MATERIALS AND METHODS}

\section{1- Microporpagation}

In the present study, MS medium comprising of $30 \mathrm{~g} \mathrm{~L}^{-1}$ sucrose was used for in vitro establishment and multiplication and $50 \mathrm{~g} \mathrm{~L}^{-1}$ for rooting. The $\mathrm{pH}$ of the medium was adjusted to 5.8 prior to autoclaving, using $0.1 \mathrm{~N} \mathrm{HCl} \mathrm{or} 0.1 \mathrm{~N} \mathrm{NaOH}$. Agaragar $(0.8 \%)$ was added as a gelling agent. Medium was sterilized at $121^{\circ} \mathrm{C}$ and 15 psi pressure in an autoclave for 15 minutes. Sterilized apical shoots were cultured on MS medium [33] supplemented with different concentrations of BAP and kinetin for initiation of buds under aseptic conditions. MS medium fortified with $5.0 \mathrm{mg} \mathrm{L}^{-1} \mathrm{BAP}+0.25 \mathrm{mg} \mathrm{L}^{-1} \mathrm{NAA}$ and different concentrations of adenine sulphate $\left(\mathrm{AdSO}_{4}\right)$ was used for in vitro multiplication. Elongated shoots were cultured on $1 / 2$ MS medium supplemented with different concentrations of NAA for rooting. The culture vessels were kept in growth chambers at $25 \pm 2{ }^{\circ} \mathrm{C}$ and light intensity of $100 \mu \mathrm{EM}^{-2} \mathrm{sec}^{-1}$ (1000 lux) for $16 / 8$ (light/dark) hours. The plantlets were transferred in green house for hardening. The hardened plants were screened for genetic stability using twenty six RAPD (Table 4) and twenty ISSR (Table 5) primers (IDT make).

\section{2- Genomic DNA isolation}

Genetic stability of tissue culture raised plants was tested using RAPD and ISSR markers. For this study, nine plants were selected randomly from the tissue cultured raised population of thousand hardened plants and mother plant. Young leaf tissue was used for extraction of total genomic DNA using the modified cetyl trimethyl ammonium bromide (CTAB) method as described by Murray and Thompson [34]. DNA amplification was carried out after standardizing the required amplification conditions viz. template DNA concentrations, primers, $\mathrm{MgCl}_{2}$, Taq DNA polymerase and annealing temperature. RAPD-PCR reactions were carried out in $20 \mu \mathrm{l}$ of reaction mix containing 1 X PCR buffer, $250 \mu \mathrm{M}$ dNTPs mix, $0.6 \mu \mathrm{M}$ primers, $1.5 \mathrm{mM} \mathrm{MgC1} 1_{2}, 0.5 \mathrm{U}$ Taq DNA polymerase and $50 \mathrm{ng}$ of template DNA. ISSR-PCR reaction was conducted in $10 \mu \mathrm{l}$ of reaction mix containing I X PCR buffer, $500 \mu \mathrm{M}$ dNTPs mix, $0.5 \mu \mathrm{M}$ primers, $1.5 \mathrm{mM} \mathrm{MgCl}_{2}, 1 \mathrm{U} \mathrm{Taq}$ DNA polymerase and $25 \mathrm{ng}$ of template DNA.

\section{3- PCR reaction}

\section{1- RAPD-PCR reaction}

For RAPD primers, PCR was initiated by a denaturation step at $94^{\circ} \mathrm{C}$ for 3 min followed by the reaction comprising of 40 cycles at $94^{\circ} \mathrm{C}$ for $1 \mathrm{~min}, 36^{\circ} \mathrm{C}$ for $1 \mathrm{~min}, 72^{\circ} \mathrm{C}$ for $1 \mathrm{~min}$, with a final extension step of $5 \mathrm{~min}$ at $72^{\circ} \mathrm{C}$. 


\section{2- ISSR-PCR reaction}

For ISSR primers, PCR was initiated for denaturation at $94^{\circ} \mathrm{C}$ for 4 min followed by the reaction comprising of 40 cycles at $94^{\circ} \mathrm{C}$ for $1 \mathrm{~min}, 50-65^{\circ} \mathrm{C}$ for $1 \mathrm{~min}, 72^{\circ} \mathrm{C}$ for $2 \mathrm{~min}$, with a final elongation step of $8 \mathrm{~min}$ at $72^{\circ} \mathrm{C}$. The amplified products were stored at $-20^{\circ} \mathrm{C}$ till further use.

\section{4- Visualization and products analysis}

The amplified products were resolved by electrophoretically using $2 \%$ agarose gel with ethidium bromide $\left(5 \mu \mathrm{g} \mathrm{mL} \mathrm{m}^{-1}\right) \mathrm{stain}$. Products were viewed using Alpha Digi Doc Pro ${ }^{\mathrm{TM}}$ documentation system under UV light. Unambiguous and clear amplification profiles of RAPD and ISSR markers were scored based on presence and absence of bands. Size of amplicons was recorded based on their migration relative to molecular size marker (100 bps ladder).

\section{5- Data analysis for genetic fidelity}

During data analysis each band was treated as a marker and well-resolved each fragment in the size range of 100 bps was manually scored. The scoring of RAPD and ISSR amplicons was done on the basis of their presence (' 1 ') or absence ('0') in the gel. Further the profiles were compared with each other for all the DNA samples to detect any genetic variation.

\section{RESULTS}

The experiments were conducted to study the in vitro multiplication and to access the genetic stability of micropropagated plants of banana cv. G-9.

\section{1- Micropropagation of cultivar G-9}

Effect of plant hormones viz BAP and kinetin was observed on in vitro establishment of banana cultivars G-9 and data were recorded for buds break and time required for bud initiation (Table 1, Fig. 1A). The cultivar varied in bud proliferation response to different hormones used and showed best response on $\mathrm{EM}_{4}\left(\mathrm{MS}+\mathrm{BAP} 4.0 \mathrm{mg} \mathrm{L}^{-1}\right)$ medium with maximum of 3.8 buds/explants in 2.6 days. The sprouted buds were further cultured on MS medium supplemented with $5.0 \mathrm{mg} \mathrm{L}^{-1} \mathrm{BAP}$ $+0.25 \mathrm{mg} \mathrm{L}^{-1} \mathrm{NAA}$ and varied concentrations of adenine sulphate (AdSO $)_{4}$ for in vitro multiplication (Table 2). The maximum bud multiplication was reported on medium $\mathrm{Ma}_{3}$ comprising MS medium $+5.0 \mathrm{mg} \mathrm{L}^{-1} \mathrm{BAP}+0.25 \mathrm{mg} \mathrm{L^{-1 }} \mathrm{NAA}$ of $+30 \mathrm{mg} \mathrm{L}^{-1} \mathrm{AdSO}_{4}$ (Fig. 1B). The elongated shoots were transferred on MS medium supplemented with various concentrations of auxins (NAA, IBA) and maximum rooting (100\%) was reported on $\mathrm{RM}_{4}$ medium (MS basal+ $2.0 \mathrm{mg} / \mathrm{l}$ NAA) in 12.2 days (Table 3, Fig. 1C). The rooted plants were then transplanted in green house for hardening and genetic fidelity testing (Fig. 1D).

Table 1: Effect of growth hormones on in vitro establishment of banana cultivar G-9 (average bud break \& average days required for bud break).

\begin{tabular}{|l|l|l|}
\hline \multicolumn{1}{|c|}{ Media code } & Average no. of buds /explants & $\begin{array}{l}\text { Average days required for bud } \\
\text { break }\end{array}$ \\
\hline $\mathrm{EM}_{0}$ (control) & $1.0 \pm 0.00$ & $10.6 \pm 0.24$ \\
\hline $\mathrm{EM}_{1}\left(\mathrm{BAP} 1.0 \mathrm{mg} \mathrm{L}^{-1}\right)$ & $1.6 \pm 0.08$ & $7.5 \pm 0.49$ \\
\hline $\mathrm{EM}_{2}\left(\mathrm{BAP} 2.0 \mathrm{mg} \mathrm{L}^{-1}\right)$ & $1.9 \pm 0.10$ & $6.6 \pm 0.63$ \\
\hline $\mathrm{EM}_{3}\left(\mathrm{BAP} 3.0 \mathrm{mg} \mathrm{L}^{-1}\right)$ & $2.4 \pm 0.21$ & $5.8 \pm 0.40$ \\
\hline $\mathrm{EM}_{4}\left(\mathrm{BAP} 4.0 \mathrm{mg} \mathrm{L}^{-1}\right)$ & $3.3 \pm 0.17$ & $2.6 \pm 0.37$ \\
\hline$E M_{5}\left(\mathrm{BAP} 5.0 \mathrm{mg} \mathrm{L}^{-1}\right)$ & $1.4 \pm 0.15$ & $4.7 \pm 0.17$ \\
\hline$E M_{6}\left(\mathrm{KIN} 1.0 \mathrm{mg} \mathrm{L}^{-1}\right)$ & $1.4 \pm 0.15$ & $6.6 \pm 0.63$ \\
\hline$E M_{7}\left(\mathrm{KIN} 2.0 \mathrm{mg} \mathrm{L}^{-1}\right)$ & $1.6 \pm 0.06$ & $5.8 \pm 0.40$ \\
\hline$E M_{8}\left(\mathrm{KIN} 3.0 \mathrm{mg} \mathrm{L}^{-1}\right)$ & $1.8 \pm 0.08$ & $6.9 \pm 0.36$ \\
\hline$E M_{9}\left(\mathrm{KIN} 4.0 \mathrm{mg} \mathrm{L}^{-1}\right)$ & $1.2 \pm 0.13$ & $5.8 \pm 0.40$ \\
\hline$E M_{10}\left(\mathrm{KIN} 5.0 \mathrm{mg} \mathrm{L}^{-1}\right)$ & $1.2 \pm 0.13$ & $7.3 \pm 0.36$ \\
\hline
\end{tabular}




\section{ISSN 2348-6201}

Table 2: Effect of growth hormones on in vitro multiplication of banana cultivar i.e. G-9 (average no. of shoots)

\begin{tabular}{|l|l|l|l|l|}
\hline Media code & Media combinations & \multirow{2}{|l|}{$\begin{array}{l}\text { AdSO } \\
\left(\mathrm{mg} \mathrm{L}^{-1}\right)\end{array}$} & & \multicolumn{2}{l|}{ Average no. of shoots on } \\
\cline { 3 - 5 } & & & $\mathbf{1 6}^{\text {th }}$ day & $\mathbf{2 4}^{\text {th }}$ day \\
& & & & \\
\hline $\mathrm{Ma}_{1}$ & BAP $5.0+\mathrm{NAA} 0.25 \mathrm{mg} \mathrm{L}^{-1}$ & 10.0 & $5.4 \pm 0.06$ & $12.5 \pm 0.36$ \\
\hline $\mathrm{Ma}_{2}$ & BAP $5.0+\mathrm{NAA} 0.25 \mathrm{mg} \mathrm{L}^{-1}$ & 20.0 & $6.6 \pm 0.63$ & $15.1 \pm 0.16$ \\
\hline $\mathrm{Ma}_{3}$ & BAP $5.0+\mathrm{NAA} 0.25 \mathrm{mg} \mathrm{L}^{-1}$ & 30.0 & $7.3 \pm 0.36$ & $16.5 \pm 0.06$ \\
\hline $\mathrm{Ma}_{4}$ & BAP 5.0+NAA $0.25 \mathrm{mg} \mathrm{L}^{-1}$ & 40.0 & $6.9 \pm 0.36$ & $13.3 \pm 0.63$ \\
\hline
\end{tabular}

*Mean of three replicates, $\pm=$ Standard error (mean)

Table 3: Effect of growth regulators on in vitro rooting of banana cultivar G-9 (number of days taken for visible root formation from regenerated shoots)

\begin{tabular}{|l|c|c|}
\hline \multicolumn{1}{|c|}{$\begin{array}{l}\text { Media Code } \\
1 / 2 \mathrm{MS}+50 \mathrm{~g} \mathrm{~L}^{-1} \text { Sucrose }\end{array}$} & $\begin{array}{l}\text { Percentage } \\
\text { response }\end{array}$ & $\begin{array}{l}\text { No. of days taken for visible root } \\
\text { formation* G-9 }\end{array}$ \\
\hline $\mathrm{RM}_{0}$ (control) & 20 & $17.0 \pm 0.31$ \\
\hline $\mathrm{RM}_{1}$ (NAA0.5) & 40 & $13.7 \pm 0.47$ \\
\hline $\mathrm{RM}_{2}$ (NAA1.0) & 50 & $12.6 \pm 0.32$ \\
\hline $\mathrm{RM}_{3}$ (NAA1.5) & 70 & $12.2 \pm 0.30$ \\
\hline $\mathrm{RM}_{4}$ (NAA2.0) & 30 & $15.1 \pm 0.56$ \\
\hline $\mathrm{RM}_{5}$ (IBA0.5) & 60 & $14.3 \pm 0.44$ \\
\hline $\mathrm{RM}_{6}$ (IBA1.0) & 60 & $12.7 \pm 0.35$ \\
\hline $\mathrm{RM}_{7}$ (IBA1.5) & 70 & $12.6 \pm 0.37$ \\
\hline $\mathrm{RM}_{8}$ (IBA2.0) & 30 & \\
\hline
\end{tabular}

${ }^{\star}$ Mean of three replicates, $\pm=$ Standard error (mean)

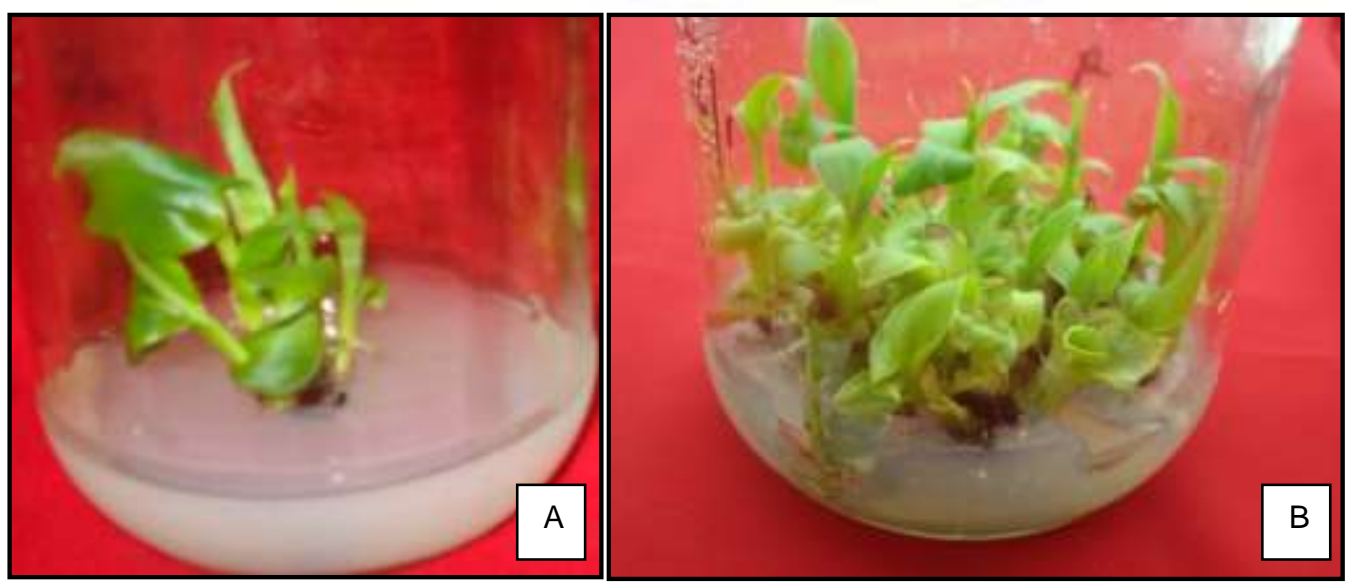



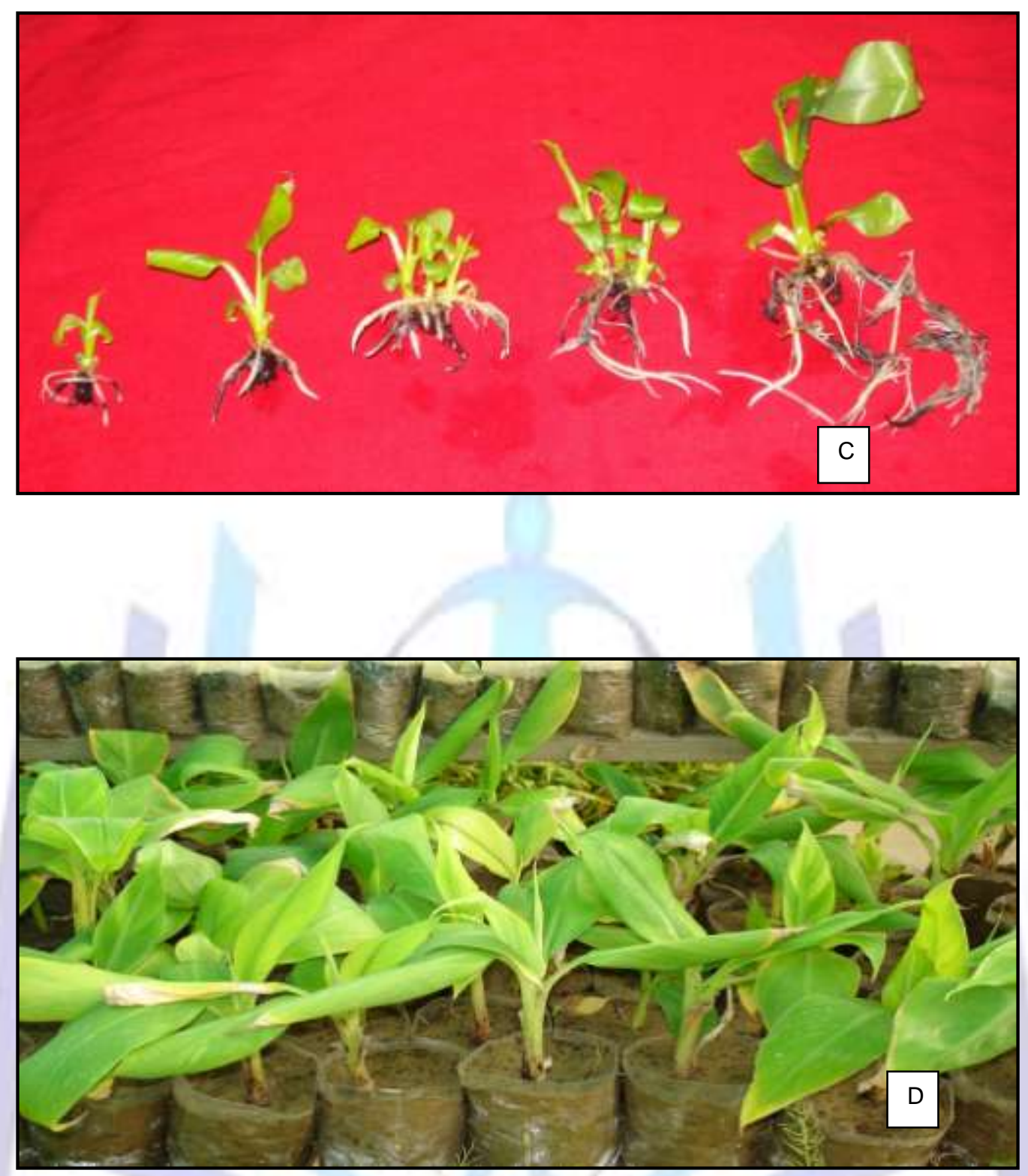

Fig 1: Micropropagation of banana cultivar G-9. A- Establishment. B- Multiplication. C- Rooting. D- Hardened plants

\section{2- Genetic stability testing of in vitro raised plants of banana cv. G-9 using RAPD \& ISSR primers}

For this study, mother plant and nine in vitro raised plants were selected randomly from the population of thousand of plants and screened for genetic stability using twenty six RAPD (Table 4) primers which produced 87 distinct and scorable bands, with an average of 3.34 bands per primer. The number of amplified bands for RAPD primers was varied between 2 (MA1, MA3, MA10, MA13, MA14, MA18, MA20) to 5 (MA2, MA4, MA8, MA9, MA21, MA25) (Table 4). The size of amplicons varied from 100 bps (MA12) to $1200 \mathrm{bps}$ (MA4). No polymorphism was detected during the RAPD analysis of in vitro raised plants (Fig. 2). Likewise twenty ISSR primers were used to detect variation in in vitro raised plants which produced 71 distinct and scorable bands in the size range of $100 \mathrm{bps}$ (MM2, MM14) to $1000 \mathrm{bps}$ (MM17). The number of amplified bands for each primer varied from 2 (MM12, MM13, MM16, MM19, MM20) to 6 (MM2) with an average of 3.55 bands per primer (Table 5). Banding pattern of all tissue culture raised plants was similar to mother plant and was monomorphic (Fig. 3). 


\section{ISSN 2348-6201}

Table 4: DNA amplification profile generated for clonal fidelity testing of in vitro propagated banana cultivar G-9 using RAPD primers.

\begin{tabular}{|c|c|c|c|c|}
\hline Sr. no. & Primer & Sequence (5'-3') & $\begin{array}{c}\text { Molecular weight } \\
\text { in bps (range) }\end{array}$ & $\begin{array}{l}\text { No. of scorable } \\
\text { bands per primer }\end{array}$ \\
\hline 1 & MA1 & TGCCGAGCTG & $600-700$ & 2 \\
\hline 2 & MA2 & AATCGGGCTG & $150-350$ & 5 \\
\hline 3 & MA3 & AGGGGTCTTG & $400-700$ & 2 \\
\hline 4 & MA4 & GGTCCCTGAC & $350-1200$ & 5 \\
\hline 5 & MA5 & GAAACGGGTG & $120-450$ & 4 \\
\hline 6 & MA6 & GTGACGTAGG & $300-700$ & 3 \\
\hline 7 & MA7 & GGGTAACGCC & $500-1000$ & 3 \\
\hline 8 & MA8 & GTGATCGCAG & $650-1100$ & 5 \\
\hline 9 & MA9 & AGCCAGCGAA & $640-850$ & 5 \\
\hline 10 & MA10 & GACCGCTTGT & $600-700$ & 2 \\
\hline 11 & MA11 & AGGTGACCGT & $250-350$ & 4 \\
\hline 12 & MA13 & CCGAACACGG & $100-450$ & 2 \\
\hline 13 & MA14 & TCGTTCCGCA & $800-900$ & 2 \\
\hline 14 & MA15 & CCTCTCGACA & $600-820$ & 3 \\
\hline 15 & MA16 & TGAGCCTCAC & $650-900$ & 3 \\
\hline 16 & MA17 & CCCAAGGTCC & $140-400$ & 4 \\
\hline 17 & MA18 & GGTGCGGGAA & $400-500$ & 2 \\
\hline 18 & MA19 & CCAGATGCAC & $500-800$ & 3 \\
\hline 19 & MA20 & GTGACATGCC & $600-700$ & 2 \\
\hline 20 & MA21 & TCAGGGAGGT & $300-1000$ & 5 \\
\hline 21 & MA22 & AAGACCCCTC & $400-1000$ & 3 \\
\hline 22 & MA23 & AGATGCAGCC & $400-1000$ & 3 \\
\hline 23 & MA25 & GAGTCTCAGG & $200-500$ & 4 \\
\hline 24 & MA26 & GGTGACTGTG & $150-600$ & 5 \\
\hline 25 & MA27 & GGCACGTAAG & $550-800$ & 3 \\
\hline 26 & MA28 & AAGTCCGCTC & $300-500$ & 3 \\
\hline \multicolumn{4}{|c|}{ Total } & 87 \\
\hline \multicolumn{4}{|c|}{ Mean } & 3.34 \\
\hline
\end{tabular}


Table 5: DNA amplification profile generated for clonal fidelity testing of in vitro propagated banana cultivar G-9 using ISSR primers.

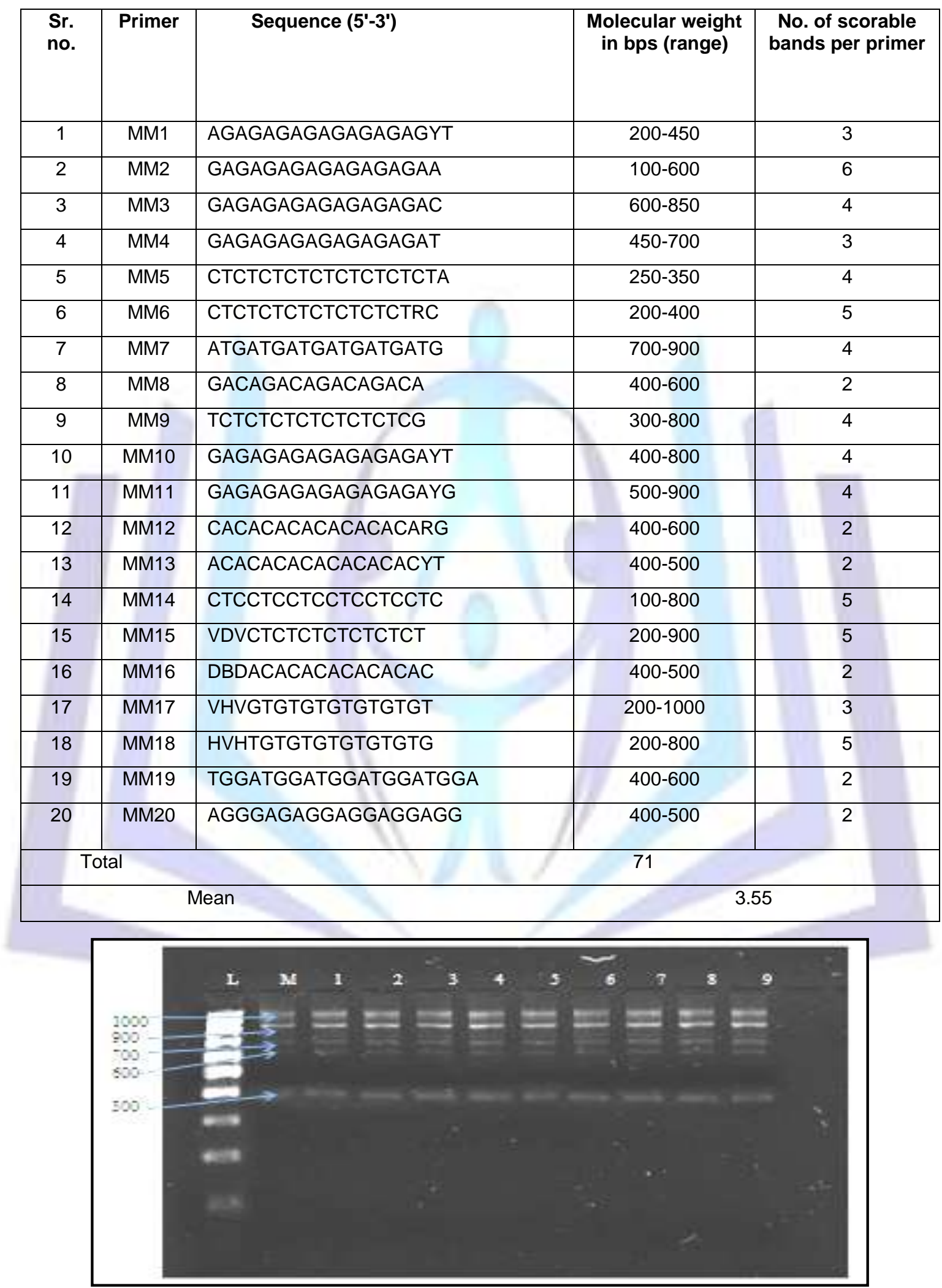

Fig 2: RAPD profiles of mother plant (M) and tissue culture raised (1-9 lanes) plants using primer MA-21. 


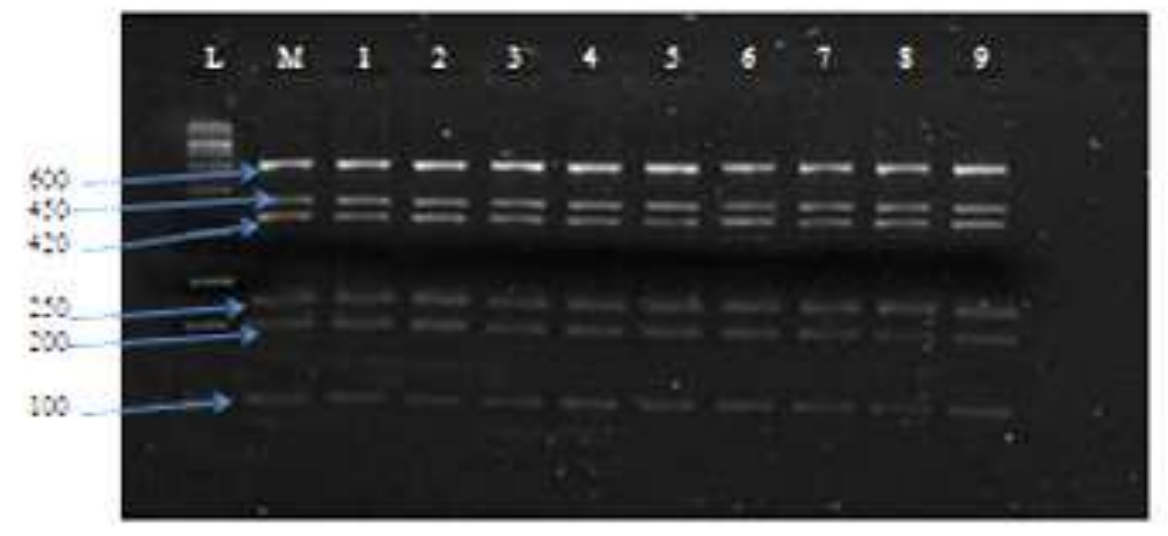

Fig 3: ISSR profiles of mother plant (M) and nine tissue culture raised (1-9 lanes) plants using the primer MM-2.

\section{DISCUSSION}

Venkatachalam [35] reported the similar results on MS medium supplemented with $5.0 \mathrm{mg} \mathrm{L}^{-1}$ BAP. Effect of different combination of growth hormones on in vitro propagation of banana genotypes was also observed by many workers [36, $37,38,39,40,14,15]$. The elongated shoots were cultured on $1 / 2 \mathrm{MS}$ liquid media fortified with $50.0 \mathrm{~g} \mathrm{~L}^{-1}$ sucrose and different concentrations of NAA (Table 3 ). The maximum rooting response (100\%) was reported on $1 / 2$ MS liquid media supplemented with $2.0 \mathrm{mg} \mathrm{L}^{-1}$ NAA (Fig 1C) in 12.2 days. Al-Amin et al. [41] and Ganapathi et al. [42] also reported that root numbers varied with different concentrations of IBA, IAA and NAA and results obtained were in similar pattern. In vitro rooted shoots were successfully transferred in green house without any mortality (Fig. 1D).

Molecular markers are considered to be reliable in monitoring genetic variability in plants [43].RAPD technique was used by several authors to investigate the genetic variability and found it to be very efficient and reliable[26, 22, 23, 24 ].Results obtained using RAPD were similar with those obtained with restriction fragment length polymorphism (RFLP) and isozymes [44]. Banding patterns obtained using RAPD technique can be used to develop genotype-specific cultivar identification. DNA profiling and reproducibility of RAPD technique is influenced by any variation in the methods used for isolation of genomic DNA [45], template DNA, primer, Taq-DNA polymerase concentration, annealing temperature, number of thermal cycles and $\mathrm{MgCl}_{2}$ concentration[46, 47]. Many reports are available which suggest that the majority of RAPD bands are reproducible if standard protocol is strictly followed in each reaction $[48,49]$.

Genetic fidelity assessment of banana cv. G-9 using RAPD and ISSR primers reveals that all the micropropagated plants were true to type. The uses of two types of markers, which amplify different regions of the genome, allow better chances for identification of genetic variations in the plantlets. In this study RAPD's and ISSR markers have been used for analysis of variants as they offer several advantages over other conventional methods. These molecular markers are technically simple, inexpensive, require very little plant material, quickly to perform and yields true genetic markers study [50]. Shenoy and Vasil [51] reported that micropropagation through meristem culture are generally less subjected to genetic changes that might occur during cell differentiation under in vitro conditions. Ray et al. [52] also observed the genetic stability of the tissue culture raised plants of three banana cultivars i.e. G-9 (AAA), Giant Govenor (AAA) and Martaman (AAB) by using 21 RAPD and 12 ISSR primers. And found three somaclonal variants from 'G-9' and three from 'Giant Govenor". Harirah and Khalid [53] used eighteen arbitrary decamer primers to study the genetic fidelity of banana cv. Berangan and found that all the regenerated plants were monomorphic in nature. Similarly, Choudhary et al. [54] also reported genetic stability of banana cultivar-Robusta using RAPD and ISSR markers. In some cases, regeneration process is prone to somatic variation resulting in off-types as in case of Populus termuloides [55] and tea clones [56]. Variations are induced by different genetic and epigenetic mechanisms that are likely to be reflected in the banding pattern developed by employing different marker system. However, the reliability and efficiency of molecular markers in detecting large scale genome arrangements have been frequently questioned. Since simple sequence repeat based primer target the fast evolving and hyper variable DNA sequence. ISSR markers are considered suitable to detect variation among micropropagated plants $[55,52,57]$. RAPD and ISSR markers have also been successfully used to determine genetic diversity and relationships amongst Musa germplasm [58, 59, 60,61].The use of ISSR \& RAPD to discriminate between somatic mutants and the clone from which the mutants originated have also been studied in banana [35].

\section{CONCLUSIONS}

In the present study, no polymorphism was detected during the RAPD \& ISSR analysis of in vitro raised clones. A homogenous amplification profile was observed for all the micropropagated plants when compared to mother plant in both types of markers used. The results corroborate the fact that in vitro multiplication is the safest mode for production of true 
to type of plants. So this methodology not only provide the homogenous planting material but also useful in conservation of elite traits of specific planting material. It can be used to provide disease free and quality planting material (banana plants) to the farmers which will help in the upliftment of economic status of the farmers as well as the country.

\section{ACKNOWLEDGEMENTS}

The authors thank the Director (T), Centre for Plant Biotechnology, Hisar and Chairperson, Department of Biotechnology, Ch. Devi Lal University, Sirsa for providing the necessary laboratory facilities.

\section{Competing of interest}

The author(s) declare that they have no competing interests.

\section{REFERENCES}

[1] Daniels, D., Kosky, R. G. \& Vega, M. R. (2002).Plant regeneration system via somatic embryogenesis in the hybrid cultivar FHIA-21 (Musa sp. AAAB group). In Vitro Cell Dev Biol Plant, 38, 330-333.

[2] Singh, R. (1969).Fruits.National Book Trust, New Delhi, India, Pp, 213.

[3] Subramanyam, K., Subramanyam, K., Sailaja, K. V., Srinivasulu, M. \& Lakshmidevi, K. (2011).Highly efficient Agrobacterium-mediated transformation of banana cv. Rasthali (AAB) via sonication and vacuum infiltration. PInat Cell Rep, 30, 425-436.

[4] KTL Fineli, 2007. Banana without peel, (Finnish National Public Health Institute). Available online: http://www.fineli.fi/food.php?foodid=11049\&lang=en,

[5] Vuylsteke, D. \& Dc Langhe, E. A. L. (1985).Feasibility of in vitro propagation of bananas and plantains. Tropical Agriculture (Trinidad), 62, 323-328.

[6] Wong, W. C. (1986). In vitro propagation of banana (Musa spp.) initiation, proliferation and development of shoot-tip cultures on defined media. Plnat Cell Tissue Organ \& Culture, 6, 159-166.

[7] Banerjee, N. \& Dc Langhe, D. E. (1985). A tissue culture technique for rapid clonal propagation and storage under minimal growth conditions of Musa (banana and plantain). Plant Cell Researh, 4, 351-354.

[8] Vuylsteke, D. R. (1989).Shoot-tip culture for the propagation, conservation and exchange of Musa germplasm. Practical manuals for handling crop germplasm in vitro, INBPGR, Rome.

[9] Israeli, Y., Lahav, E. \& Reuveni, O. (1995). In vitro culture of bananas, in Bananas and Plantains, edited by : Gowen S (Chapman and Hall, London U.K.), 147-175.

[10] Kajla, S., Poonia, A. K., Kharb, P., Duhan, J. S. (2014). Role of Biotechnology for commercial Production of Fruit Crops, in Biotechnology: Prospects and Applications, edited by Salar RK, Gahlawat SK, Siwach P, Duhan JS (Springer, New Delhi, Heidelberg, New-York, Dordrecht, London) 2014, 27-38.ISBN 978-81-322-1682-7 ISBN 978-81322-1683-4 (eBook) DOI 10.1007/978-81-322-1683-4, 2014.

[11] Etienne, H. \& Berthouly, M. (2002).Temporary immersion in plant micro-propagation. Plant Cell Tissue Organ \& Culture, 69, 215-231.

[12] Kadota, M. \& Niimi, Y. (2003). Effects of cytokinin types and their concentrations on shoot proliferation and hyperhydrocity in vitro pear cultivar shoots. Plant Cell Tissue Organ \& Culture, 72, 261-265.

[13] Kajla, S., Goyal, S., Poonia, A. K., Sehrawat, A. R. \& Dhawan, A. K. (2012). An efficient protocol for large scale production and effect of various chemicals and growth substances on micropropagation of elite sugarcane cultivar $\mathrm{CoH}-119$, in Crop Science and Technology for Food Security, Bioenergy and Sustainability, edited by Behl RK, Bona L, Pauk J, Merbach W, Veha A (Agrobios (International), Jodhpur, India), 45-53.

[14] Choudhary, D., Kajla, S., Duhan, J. S., Poonia, A. K., Surekha \& Kharb, P. (2013).Comparative study of various growth regulators on in vitro multiplication of commercial cultivar of banana Grand naine (G-9). Annal Biology, 29(3), 288-293.

[15] Choudhary, D., Kajla, S., Poonia, A. K., Duhan, J. S., Kumar, A. \& Kharb, P. (2014). An efficient micropropagation protocol for Musa paradisiaca cv. Robusta: A commercial cultivar. Annal Biology, 30(1), 25-31.

[16] Rout, G. R., Senapati, S. K., Aparajita, S. \& Palai, S. K. (2009).Studies on genetic identification and genetic fidelity of cultivated banana using ISSR markers. PInat Omics Journal, 2(6), 250-258.

[17] Bhatia, R., Singh, K. P., Sharma, T. R.\& Jhang, T. (2011).Evaluation of the genetic fidelity of in vitro propagated gerbera (Gerbera jamesonii Bolus) using DNA-based markers. Plant Cell Tissue Organ \& Culture, 104, $131-135$.

[18] Gaafar, R. M. \& Saker, M. M. (2006). Monitoring of cultivars identity and genetic stability in strawberry varieties grown in Egypt. World Journal Agricultural Science, 2 (1), 29-36.

[19] Kjeldgaad, R. H. \& Marsh, D. R. (1994). Intellectual property rights for plants. Plnat Cell, 6, 1524-1528. 


\section{ISSN 2348-6201}

[20] Kester, D. E. (1983). The clone in horticulture. Horticulture Science, 75, 831-837.

[21] Soniya, E. V., Banerjee, N. S. \& Das, M. R. (2001).Genetic analysis of somaclonal variation among callus-derived plants of tomato. Current Science, 80, 1213-1215.

[22] Samantaray, S. \& Maiti, S.(2010).An assessment of genetic fidelity of micropropagated plants of Chlorophytum borivilianum using RAPD markers. Biologia Plantarum, 54(2), 334-338.

[23] Das, A., Kesari, V., Rangan, L. (2010).Plant regeneration in Curcuma species and assessment of genetic stability of regenerated plants, Biologia Plantarum, 54(3), 423-429.

[24] Mohanty, S., Panda, M. K., Sahoo, S. \& Nayak, S. (2011).Micropropagation of Zingiber rubens and assessment of genetic stability through RAPD and ISSR markers. Biologia Plantarum, 55(1), 16-20.

[25] Damiano, C., Monticelli, S. \& Corazza, L. (1997).Somaclonal variability and in vitro regeneration of strawberry. Acta Hort, 447, 87-93.

[26] Brown, P. T., Lang, F. D., Kranz, E. \& Lorz, H. (1993).Analysis of single protoplasts and regenerated plants by PCR and RAPD technology. Mol Gen Genet, 237, 311-317.

[27] Godwin, I. D., Sangduen, N., Kunanuvatchaidach, R., Piperidis, G., Adkins, S. W. (1997).RAPD polymorphisms among variants and phenotypically normal rice (Oryza sativa var. Indica) somaclonal progenies. Pl Cell Rep, 16, 320-324.

[28] Vijay, R., Parida, A. \& Raina, S. N. (1995). Random amplified polymorphic DNA (RAPD) markers for genetic analysis in micropropagated plants of Populus deltoides March. Pl Cell Rep, 14, 459-462.

[29] Saker, M. M., Bekheet, S. A., Taha, H. S., Fahmy, A. S \&, Moursy, H. A. (2000). Detection of somaclonal variations in tissue culture-derived date palm plants using isozyme analysis and RAPD fingerprints. Biol Pl, 43, 347-351.

[30] Saker, M., Adawy, S. S., Mohamed, A. A. \& El-Itriby, H. A. (2005).Monitoring of cultivar identity in tissue culturederived date palms using RAPD and AFLP analysis. Biol PI, 50, 198-204.

[31] Hernandez, R., Rodriguez, R., Ramirez, T., Canal, M. J., Guillen, D., Noceda, C., Escalona, M., Corujo, M. \& Ventura, J. (2007). Genetic and morphoagronomic characterization of plantain variants of Musa AAB clone CEMSA. J Food Agri Environ, 5, 220-223

[32] Sheidai, M., Aminpoor, H., Noormohammadi, Z. \& Farahani, F. (2010). Genetic variation induced by tissue culture in Banana (Musa acuminate L.) cultivar Cavandish Dwarf. Gene Conserve, 9, 1-10.

[33] Murashige, T. \& Skoog, F. (1962).A revised medium for rapid growth and bioassays with tobacco tissue cultures. Physiol PI, 15, 473-497.

[34] Murray, H. G. \& Thompson, W. F. (1980).Rapid isolation of high molecular weight DNA. Nucleic Acids Res, 8, 43214325.

[35] Venkatachalam, L., Sreedhar, V., Bhagyalakshmi, (2007). Genetic analyses of micropropagated and regenerated of banana as assessed by RAPD and ISSR markers. In Vitro Cellular Dev Biol Plant, 43, 267-274.

[36] Cronauer, S. S. \& Krikorian, A. D. (1986).Banana (Musa spp). In: Bajaj YPS (ed) Biotechnology in agriculture and forest Trees. Springer, Berlin - Heidelberg - New York Vol.1 Pp. 233-252.

[37] Jarret, R. L. (1986).In vitro propagation and genetic conservation of bananas and plantains. - In: Anonymous (ed) IBPGR Advisory Committee on in vitro Storage.Report of the third meeting.International Board for Plant Genetic Resources, Rome Pp.15-33.

[38] Diniz, J. D. N., Goncalves, A. N., Hernandez, F.F.F. \& Torres, A. C. (1999). Macronutrient absorption by banana explants in vitro. Pesqui Agropecu Bras, 34(7), 1201-1209.

[39] Krishnamoorthy, V., Kumar, N., Sooriananthasundaram, K. (2001).In vitro propagation of the popular desert cv. Poovan $(A A B)$. First post graduate seminar. TNAU, Coimbatore 46.

[40] Kagera, A. G., Kagera, G. R., Kegera, C. B. M., Van den Houwe, I. \& Swennen, R. (2004).Rapid mass propagation and diffusion of new banana verities among small scale farmers in North Western Tazania. Afr Crop Sci J, 12(1), 7 17.

[41] Al-Amin, M. D., Karim, M. R., Amin, M. R., Rahman, S. \& Mamun, A. N. M. (2009).In vitro micropropagation of banana (Musa spp.). Bangladesh J Agri Res, 34(4), 645-659.

[42] Ganapathi, T. R., Srinivas, I., Suprasanna, P., Bapat, V. A. (2001).Regeneration of plants from alginatedencapsulated somatic embryos of banana cv. Rasthali (spp. AAB group). Biol Pl, 37,178-181.

[43] Zerihun, D., Vashist, U. \& Boora, K. S.(2009).Molecular characterization of citrus cultivars using DNA Markers. Int J Biotechnol \& Biochem, 5(3), 271-280.

[44] Sabir, A., Newbury, H. J., Todd, G., Catty, J. \& Ford-Lloud, B. V. (1992). Detection of genetic stability using isozymes and RFLPs in beet plants regenerated in vitro. Theor Appl Genet, 84, 113. 
[45] Korbin, M., Kuras, A., Golis, A., Òurawicz, E. (2000).Effect of DNA quality on randomly amplified polymorphic DNAbased identification of strawberry (Fragaria ananassa) genotypes. J Fruit Ornamental PI Res, 8, 107-115.

[46] Bassam, B. J., Caetano-Anolles, G. \& Gresshoff, P. M. (1992).Amplification fingerprinting of bacteria.Applied Microbiol, 38, 70-76.

[47] Kernodle, S. P., Cannon, R. E. \& Scandalios, J. G. (1983).Concentration of primer and template qualitatively affects products in random-amplified polymorphic DNA PCR. Biotechnol, 14, 362- 364.

[48] Hedrick, P. (1992).Shooting the rapids, Nature, 355, 679-680.

[49] Gibbs, H. L., Prior, K. A. \& Weatherhead, P. J. (1994).Genetic analysis of populations of threatened snake species using RAPD markers. Mol Ecol, 3, 329-337.

[50] Rafalski, J. A., Vogel, J. M., Morgante, M., Powell, W., Andre, C. \& Tingey, S. V. (1996).Generating and using DNA markers in plants. In: Birren B, Lai $E$ (ed) Non-mammalian genomic analysis. A practical guide. Academic Press, London, Pp. 75-134.

[51] Shenoy, V. B. \& Vasil, I. K. (1992).Biochemical and molecular analysis of plants derived from embryogenic tissue cultures of napier grass (Pennisetum purpureum K. Schum). Theor Appl. Genet, 83, 947-952.

[52] Ray, T., Indrajit, I., Saha, P., Sampa, D. A. S. \& Roy, S. C. (2006).Genetic stability of three economically important micropropagated banana (Musa spp.) cultivars of lower Indo-Gangetic plains, as assessed by RAPD and ISSR markers. Pl Cell Tiss Org Cult, 85, 11-21.

[53] Harirah, A. A. \& Khalid, N. (2006).Direct regeneration and RAPD assessment of male inflorescence derived plants of Musa acuminata cv. Berangan. Asia Pacific J Mol Biol Biotech, 1, 11-17.

[54] Choudhary, D., Kajla, S., Poonia, A. K., Brar, B., Surekha \& Duhan, J. S. (2014).Comparative molecular assessment of genetic stability using ISSR and RAPD markers in naturally grown and in vitro multiplied copies of commercial banana cv. Robusta. Indian Journal Biotechnology. (In press).

[55] Rahman, M. H. \& Rajora, O. P. (2001).Microsatellite DNA somaclonal variation in micropropagated trembling aspen (Populus tremuloides). Pl Cell Reports, 20 (6), 531-536.

[56] Devarumath, R. M., Nandy, S., Ravi, V., Marimuthu, S., Muraleedharan, N. \& Raina, S. N. (2002). RAPD ISSR and RFLP fingerprints as useful markers to evaluate genetic integrity of micropropagated plants of three diploid and triploid elite tea clones representing Camelliasinensis (China type) and C. assamicas sp. Assamica (Assam-India type). Plant Cell Res, 21, 166-173.

[57] Joshi, P. \& Dhawan, V. (2007).Assessment of genetic fidelity of micropropagated Swertia chirayita plantlets by ISSR marker assay. Biol Pl, 51, 22-26.

[58] Jain, P. K., Saini, M. L., Pathak, H. \& Gupta, P. K. (2007).Analysis of genetic variation in different banana (Musa species) variety using random amplified polymorphic DNAs (RAPDs). African J. Biotechnol, 6, 1987-1989.

[59] Racharak, P. \& Eiadthong, W. (2007).Genetic relationship among subspecies of Musa acuminata Colla and Agenome consisting edible cultivared bananas assayed with ISSR markers. Songklanakarin J Sci Tech, 29, 14791489.

[60] Agoreyo, B. O., Golden, K. D. \& Brown, S. E. (2008).Analysis of genetic variability among plantain cultivars (Musa paradisiaca L.) using arbitrarily primed PCR technique. African J Biotech, 7, 1041-1045.

[61] Brown, N., Venkatasamy, S., Khittoo, G., Bahorun, T., Jawaheer, S. (2009).Evaluation of genetic diversity between 27 banana cultivars (Musa spp.) in Mauritius using RAPD markers. African J Biotech, 8, 1834 -1840. 